\title{
RATING DECISION ANALYSIS BASED ON IOS APP STORE DATA
}

\author{
DOI: 10.12776/QIP.V18I2.337
}

\author{
DEJAN ERIĆ, RADOVAN BAČÍK, IGOR FEDORKO
}

Received 20 June 2014, Revised 07 October 2014, Accepted 10 November 2014

\section{INTRODUCTION}

There are several options for monetizing an app, including in-app advertising, sponsorships and in-app purchases. But for many developers, the most obvious option is simply to charge users to download their apps. Having great app ratings and user reviews is the goal of every developer of mobile applications.

This paper explores impact of pricing strategy of the applications to user evaluations. In general, ICTs play significant role to improve marketing and customer satisfaction processes (Dorcak and Delina, 2011; Gavurová, et al., 2014). Mobile services and platforms have indisputably achieved critical mass in the information and communications technology industry (Kim, et al., 2010; Kim, et al., 2012). Especially, mobile service business has moved into a new epoch due to the emergence of new mobile devices and the explosive growth in mobile application services available at "App Stores". New smart computing devices such as smartphones and tablet PCs offering traditional wireless voice services and Internet access have recently gained prominence by replacing traditional PCs. The interest in smartphone industry is understandable, mobile app stores will see annual downloads reach 102 billion in 2013, up from 64 billion in 2012, according to Gartner, Inc. (2014). Total revenue in 2013 will reach $\$ 26$ billion, up from $\$ 18$ billion in 2012. Free apps will account for 91 percent of total downloads in 2013 (see Table 1). Gartner, Inc. (2014) said that in-app purchases will account for 48 percent of app store revenue by 2017, up from 11 percent in 2012. In-app purchase was one of the more exciting and highly anticipated features introduces in iPhone SDK 3.0.

The option to integrate e-commerce within both free and paid iOS apps opened up a new frontier for developers to create additional revenue opportunities beyond just traditional app sales (Wooldridge and Schneider, 2011). The key to their success has been mobile app services, including native software or content and primary channels for connecting to Internet-based services that offer good 
smartphone user experiences (Kenney and Pon, 2011). In contrast to standard mobile phones, "smartphones" are powerful computing devices offering traditional wireless voice service as well as native software applications and, perhaps most importantly, the ability to connect to and run a myriad of Internetbased services including email, geo-location, streaming video, and social networking, while providing a good user experience.

Worldwide combined shipments of devices (PCs, tablets, ultramobiles and mobile phones) are projected to reach 2.5 billion units in 2014, a 6.9 percent increase from 2013, according to Gartner, Inc. (2014a). Device shipments grew 4.8 percent in 2013. Sales of traditional PCs will continue to hamper the overall growth of devices, and substitution from PC to tablet will decline. To complicate the landscape, the smartphone is not the only device at stake, tablets and ebook readers are emerging as key components of the mobile universe. Across all devices, total mobile revenues-including advertising, subscriptions, handsets, applications, and so on-are forecast to surpass $\$ 1$ trillion by 2014 . Given the rate at which smartphone are penetrating the market and component prices are declining by 2015 there will be, at least, 2 billion smart mobile devices in use globally (Kenney and Pon, 2011).

Consumer software applications that run on smartphones (popularly known as mobile apps) represent the fastest growing consumer product segment in the annals of human merchandising (Ben, 2011; Bilton, 2011). Mobile app services as its distribution channel have proliferated since the Apple App Store launched on July 10, 2008. Due to the store's open concept, any developer with expertise can freely create a mobile app service (Laudon and Traver, 2010; Suh, et al., 2012). Thus, full-scale innovation has occurred in various mobile service sectors, such as content services (e.g., e-book, news) and traditional offline services (e.g., banking, healthcare) (Murray, et al., 2010), as indicated by the many categories used in App Stores. Companies can now deliver a wide range of businesses and services (including e-mail, streaming video, social networking, and locationbased services) through mobile app services and this strive for competitive edges in the mobile service marketplace (Wang, et al., 2006; Murray, et al., 2010). The huge number of apps and their increasing growth rate has created number of problems for the key constituents of app ecosystem.

For consumers, there are simply too many apps and far too much fragmentation in these apps (e.g. a large number of categories). The analogy we often use to describe the confusion faced by a mobile app consumer is to imagine a customer walking into a grocery store, needing only a few items, and finding that all aisles and category labels have been eliminated, and every product has been thrown into a pile on the floor (Datta, et al., 2013). In the same way it is a daunting task for a consumer to navigate through the native app stores (Google 2014; Apple 2014) and discover apps they need and like.

This issue has raised concerns in the recent media forums (Bowman, 2011; Agarwal, 2011). Its current importance has prompted various discussions in the literature on App Store issues, such as its market outlook and possible strategies 
(Kimbler, 2010; White, 2010; Kim et al., 2014), changes in the mobile ecosystem and in the industry-level business model driven by the App Store (Holzer and Ondrus, 2011; Müller, et al., 2011), and the diffusion and adoption of user-level mobile innovations (Verkasalo, et al., 2011). However, empirical investigations of the structures and contents of mobile app services, especially those focusing on mobile apps as such, are few (Szabo, et al., 2013; Šoltés and Gavurová, 2013; Gavurová, 2011; 2012). The open platform structure of mobile app service development allows services to be indiscriminately and instantaneously created by third parties (Danado, et al., 2010; Kim, et al., 2014). Within whole mobile applications environment, user ratings play a significant role of user satisfaction and decision support building a trust into respective e-service (Užík and Šoltés, 2009).

\section{METHODOLOGY}

iOS (previously iPhone OS) is a mobile operating system developed by Apple Inc. and distributed exclusively for Apple hardware. In-App Purchase lets developers sell a variety of items directly within free or paid app, including premium content, virtual goods, and subscriptions. The analysis deals with user reviews of mobile applications for the iOS mobile platform. Article specifically focuses on the comparison of the price impact and factor in-app purchase for its user evaluation.

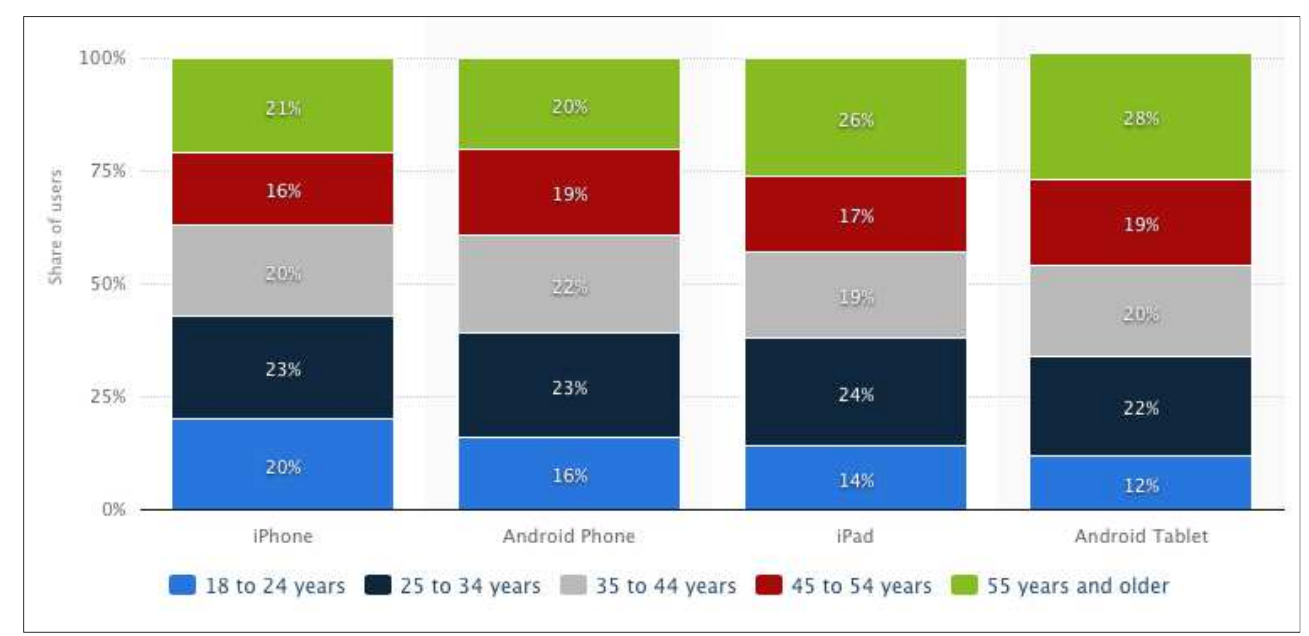

Figure 1 - Distribution of mobile app platform audiences in the United States as of June 2014, by age group (ComScore, 2014)

For this study, we primarily focus on the United States, since this country is the biggest country in terms of revenue. The reporting period covers May 2014, unless otherwise stated. In general, two kinds of categories can be identified in the Apple App Store: free apps and paid apps. The research consisted of 969 apps from App Store Top Chart rankings. Two main factors impacted App Store rank: 
download volume and velocity of those downloads. In order to rise up the ranks, app needed lots of downloads in a short amount of time. Position changes also correlated with the apps ratings (Cummings, 2013). And to maintain that rank, app needed to continue acquiring new downloads.

To identify watched subjects - mobile applications from website https://itunes.apple.com/us, we used method of automatic data collection which was used by a script of programming language PHP 5.4.25, MySQL 5.5.36 databases and web server Apache 2.4.7. In addition, two individual scripts, adapted to source code of the selected online portals, were created for the identification and database recording of the variables, such as app name and url linked to an app subpage (profile) containing customers' evaluations, free/paid status and use of in-app factor. There were 969 apps identified as follows: free: 483 (49.79\%), paid: 487 (50.21\%). Overall, we evaluated 48,374,030 user ratings. We used the SPSS Statistics software for statistical evaluation.

Table 1 - Overview of analysed applications

\begin{tabular}{lcccr}
\hline Price & Number of apps & \multicolumn{3}{c}{ Number of ratings } \\
\hline N & $\%$ & N & $\%$ \\
\hline Free apps & 483 & 49.85 & $39,690,485$ & 82.05 \\
Paid apps & 486 & 50.15 & $8,683,545$ & 17.95 \\
\hline Overall & 968 & 100.00 & $48,374,030$ & 100.00 \\
\hline
\end{tabular}

Source: own elaboration

Table 2 - Overview of analysed apps with in-app purchase factor

\begin{tabular}{lcccc}
\hline Price & Number of apps & \multicolumn{3}{c}{ Number of ratings } \\
\hline & N & $\%$ & N & $\%$ \\
\hline Free apps & 243 & 54.85 & $20,703,843$ & 75.81 \\
Paid apps & 200 & 45.15 & $6,605,193$ & 24.19 \\
\hline Overall & 443 & 100.00 & $27,309,036$ & 100.00 \\
\hline
\end{tabular}

Source: own elaboration

\section{RESULTS}

Taking a detailed look at the individual applications reviews (Table 3), we see that the vast majority of them evaluates the sample of mobile applications positively. Users can evaluate the application used by them on a 5-point scale assessments in accordance with their satisfaction level of the application. In both categories they are in first place of the most positive assessment - a free 
downloadable applications at a rate of $63.50 \%$ and paid apps at a rate of $73.44 \%$. More dissatisfied users in percentage terms can be found in free applications where this indicator has a value of $9.91 \%$ of the total $39,690,485$ user reviews.

Table 3 - Total number of customers evaluating apps

\begin{tabular}{lcccc}
\hline Rating & \multicolumn{2}{c}{ Free apps } & \multicolumn{2}{c}{ Paid apps } \\
\hline & $\mathbf{N}$ & $\%$ & $\mathbf{N}$ & $\%$ \\
\hline $5 * * * * *$ & $25,205,040$ & 63.50 & $6,377,401$ & 73.44 \\
$4 * * * *$ & $5,764,119$ & 14.52 & $1,081,548$ & 12.46 \\
$3 * * *$ & $3,016,538$ & 7.60 & 467,726 & 5.39 \\
$2 * *$ & $1,771,568$ & 4.46 & 257,807 & 2.97 \\
$1 *$ & $3,933,211$ & 9.91 & 499,063 & 5.75 \\
\hline Overall & $39,690,485$ & 100.00 & $8,683,545$ & 100.00 \\
\hline
\end{tabular}

Source: own elaboration

Similar values of user reviews can be seen in Table 4, which deals with the applications evaluation with a possibility of in-app purchase. According to free apps, users were most satisfied with the number of 14,016,862 (67.70\%) of the total set of 20,703,843 ratings. Paid apps again recorded a slightly higher support rate expressed at a rate of $75.50 \%$ of the total 6,605,193 user ratings.

Table 4 - Total number of customers evaluating apps with in-app purchase factor

\begin{tabular}{lcccc}
\hline Rating & \multicolumn{1}{c}{ Free apps } & \multicolumn{3}{c}{ Paid apps } \\
\hline $\mathbf{N}$ & $\mathbf{N}$ & $\mathbf{N}$ & $\%$ \\
\hline $5 * * * *$ & $14,016,862$ & 67.70 & $4,986,730$ & 75.50 \\
$4 * * *$ & $3,003,989$ & 14.51 & 787,722 & 11.93 \\
$3 * * *$ & $1,397,806$ & 6.75 & 334,972 & 5.07 \\
$2 * *$ & 746,460 & 0.36 & 176,110 & 0.27 \\
$1 *$ & $1,538,717$ & 7.43 & 319,659 & 4.84 \\
\hline Overall & $20,703,843$ & 100.00 & $6,605,193$ & 100.00 \\
\hline
\end{tabular}

Source: own elaboration

Look at these statistics suggests that paid applications are evaluated more positively. From the results we have achieved in research we assume that paid apps are users rated more positively, than a free application. For statistical evaluation we decided to use a two-dimensional inductive statistics tool - two- 
sampled Student's t-test, which is mostly used to check whether the samples observed difference in diameter can only be random or statistically significant. Significant difference means there is a relationship between the interval a binary variable.

Therefore, we have the following hypotheses as follows:

H0: Average review of free and paid apps are the same and therefore we expect equity of averages of two basic groups.

Ha: Average review of paid apps is higher than free apps and thus averages of essential files are not equal.

Level of statistical significance was determined at $\alpha=0.05$. P value of the test of statistical significance amounted to 0.006 (see Table 6), the null hypothesis is rejected, there is a relationship between variables. P-value $<0.01$ means statistically highly significant relationship. The research results indicate that the average review of paid apps is higher than free apps.

Table 5 - Group statistics

\begin{tabular}{lrrrr}
\hline APPs status & N & Mean & Std. Deviation & $\begin{array}{r}\text { Std. Error } \\
\text { Mean }\end{array}$ \\
\hline free & 483 & 4.03334585 & .657011044 & .029895038 \\
paid & 486 & 4.14393751 & .584816766 & .026527827 \\
\hline
\end{tabular}

Source: own elaboration

Table 6 - Independent Samples Test

\begin{tabular}{|c|c|c|c|c|c|c|c|c|c|}
\hline \multicolumn{3}{|c|}{$\begin{array}{l}\text { Levene's test for } \\
\text { Equality of Variances }\end{array}$} & \multicolumn{7}{|c|}{ t-test for Equality of Means } \\
\hline \multirow{2}{*}{\multicolumn{2}{|c|}{$\mathbf{F}$}} & \multirow[t]{2}{*}{ Sig. } & \multirow[t]{2}{*}{$\mathbf{t}$} & \multirow[t]{2}{*}{ df } & \multirow[t]{2}{*}{ p-val. } & \multirow{2}{*}{$\begin{array}{c}\text { Mean } \\
\text { difference }\end{array}$} & \multirow{2}{*}{$\begin{array}{l}\text { Std. Error } \\
\text { Difference }\end{array}$} & \multicolumn{2}{|c|}{$\begin{array}{l}\text { 95\% Confidence } \\
\text { Interval of the } \\
\text { Difference }\end{array}$} \\
\hline & & & & & & & & Lower & Upper \\
\hline $\begin{array}{l}\text { Equal } \\
\text { variances } \\
\text { assumed }\end{array}$ & 8.093 & .005 & -2.768 & 967 & .006 & -.1105917 & .03995362 & -.1889975 & -.0321859 \\
\hline $\begin{array}{l}\text { Equal } \\
\text { variances } \\
\text { assumed }\end{array}$ & & & -2.767 & 952.81 & .006 & -.1105917 & .03996797 & -.1890271 & -.0321562 \\
\hline
\end{tabular}

Source: own elaboration

Apart from the overall applications evaluation we have in research also focused on the factor of in-app purchase and its impact on the applications evaluation. From previous research, we assume that the average factor applications with inapp purchase is higher than without it 
Therefore, we have the following hypotheses as follows:

H0: Average applications review with in-app purchase factor is the same as the evaluation of the classical applications and therefore we expect equity averages of two basic groups.

Ha: Average applications review with in-app purchase factor is higher than the rating of the classic applications and therefore averages of essential files are not equal.

The results of the 2-Tail T-Test indicate that the p-value is .000 . This means that there is so little chance (less than 1 in 1000) that the difference in the sample is due to sampling error that it has been rounded to zero. We reject the null hypothesis and we can conclude, that according to user applications review there is a difference between traditional applications and applications by a factor of inapp purchase.

Table 7 - Group Statistics

\begin{tabular}{lrrrr}
\hline APPs status & $\mathbf{N}$ & Mean & Std. Deviation & Std. Error Mean \\
\hline classic & 525 & 3.95678992 & .707928320 & .030867142 \\
in-app purchase & 443 & 4.24557152 & .460511479 & .021879561 \\
\hline
\end{tabular}

Source: own elaboration

Table 8 - Independent Samples Test

\begin{tabular}{|c|c|c|c|c|c|c|c|c|c|}
\hline \multicolumn{3}{|c|}{$\begin{array}{l}\text { Levene's Test for } \\
\text { Equality of } \\
\text { Variances }\end{array}$} & \multicolumn{7}{|c|}{ t-test for Equality of Means } \\
\hline & \multirow[t]{2}{*}{$\mathbf{F}$} & \multirow[t]{2}{*}{ Sig. } & \multirow[t]{2}{*}{$\mathbf{t}$} & \multirow[t]{2}{*}{ df } & \multirow[t]{2}{*}{$\begin{array}{l}\text { p-val. } \\
\text { 2-tailed }\end{array}$} & \multirow[t]{2}{*}{$\begin{array}{c}\text { Mean } \\
\text { difference }\end{array}$} & \multirow[t]{2}{*}{$\begin{array}{l}\text { Std. Error } \\
\text { Difference }\end{array}$} & \multicolumn{2}{|c|}{$\begin{array}{l}\text { 95\% Confidence } \\
\text { Interval of the } \\
\text { Difference }\end{array}$} \\
\hline & & & & & & & & Lower & Upper \\
\hline $\begin{array}{l}\text { Equal } \\
\text { variances } \\
\text { assumed }\end{array}$ & 76.62 & 0.05 & -7.372 & 967 & .000 & -.2887816 & .03917366 & -.3656568 & -.2119064 \\
\hline $\begin{array}{l}\text { Equal } \\
\text { variances } \\
\text { assumed }\end{array}$ & & & -7.633 & 911.7 & .000 & -.2887816 & .03783511 & -.3630356 & -.2145276 \\
\hline
\end{tabular}

\section{CONCLUSION}

Article summarizes the evaluation of mobile applications for iOS devices in the U.S. market. The analysis shows that user applications reviews tend towards a positive evaluation. Collecting data from a total of 968 mobile applications and $48,374,030$ user reviews we found statistically significant differences in 
assessments of different categories of mobile applications and highlighted the positive impact of factors of in-app purchase for the applications evaluations.

One of the largest parts of iPhone app marketing is the pricing strategy. Business owners should not underestimate the power of positive reviews. Reviews shows people that the app is credible and makes them more likely to engage and that usually means more in-app purchasing. User reviews are an important indicator of quality applications and probably the biggest benefit of going with a paid application is the income potential. The way an application looks and operates is imperative to its success. When an application is downloaded, a user is going to open that app and will instantly form an impression which has a large impact on his assessment of app. Money can be made from free applications primarily by using a pay-per-click advertising model, which is very similar to Google Adsense. There are other methods such as in-app purchases or using a free app as a preview or "teaser" app for a paid version.

With an exponential growth in smartphone dispersion and app releases, the future of the app industry seems bright. At the same time, the fragmentation on the mobile market makes it hard for app developers to ensure a consistent experience across all devices and operating systems. Apple has enormous advantages in the sense that Apple's iPhone set the standard for the new generation of smartphones when it was first released in June 2007 with its touchscreen, direct manipulation interface and has continually been the innovator moving from the iPod to the iPhone and now the iPad using an almost seamless user experience. The popularity and elegance of Apple's product offer ample opportunity to application providers.

Paper presents position of iOS mobile applications business in the biggest country in terms of revenue - United States. We sketch possible measure of customer satisfaction measurement using software automatic identification and data capture and propose preliminary study of state of evaluating apps in iOS mobile operating system. Our challenge for the future is in depth analysis and examination of other performance attributes applications evaluation of and their impact on the actual sale at different times.

\section{REFERENCES}

Agarwal, A., 2011. Would you like to try android apps before buying? [online] Available at: http://www.labnol.org/internet/android-apps-try-beforebuying/19422/ [Accessed 5 May 2014].

Apple Inc., 2014. Apple app store. [online] Available at: https://itunes.apple.com/us [Accessed 5 May 2014].

Ben, G., 2011. Android market grows a staggering 861.5 per cent. [online] Available at: http://www.knowyourmobile.com/smartphones/smartphoneapps/ News/781397/android_market_grows_a_staggering_8615_per_cent.html [Accessed 5 May 2014]. 
Bilton, N., 2011. Mobile App Revenue to Reach $\$ 38$ Billion by 2015, Report Predicts. [online] Available at: http://bits.blogs.nytimes.com/2011/02/28/mobileapp-revenue-to-reach-38-billion-by-2015-report-predicts [Accessed 5 May 2014].

Bowman, J., 2011. Why native app stores like itunes and android marketplace are bad for mobile developers. [online] Available at: http://www.businessinsider.com/why-native-app-stores-like-itunes-and-andoidmarketplace-are-bad-business-for-mobile-developers-2011-5 [Accessed 5 May 2014].

ComScore., 2014. The U.S. Mobile App Report. [online] Available at: http://www.comscore.com/Insights/Presentations-and-Whitepapers/2014/TheUS-Mobile-App-Report [Accessed 16 September 2014].

Cummings, T., 2013. Is Apple Finally Adding Ratings Into Ranking Factors? [online] Available at: http://www.fiksu.com/blog/apple-finally-adding-ratingsranking-factors-0 [Accessed 16 May 2014].

Danado, J., Davies, M., Ricca, P. and Fensel, A., 2010. An authoring tool for user-generated mobile services. Lecture Notes in Computer Science, 6369, pp.118-127.

Datta, A., Kajanan, S. and Pervin, N., 2013. A Mobile App Search Engine. Mobile Networks and Applications, 18(1), pp.42-59.

Dorcak, P. and Delina, R., 2011. Impact of E-marketing Services on Economic Performance. Ekonomický časopis. 59(1), pp.44-58.

Gartner, Inc., 2014. Gartner Says Mobile App Stores Will See Annual Downloads Reach 102 Billion in 2013. [online] Available at: http://www.gartner.com/newsroom/id/2592315 [Accessed 5 May 2014].

Gartner, Inc., 2014a. Gartner Says Worldwide Traditional PC, Tablet, Ultramobile and Mobile Phone Shipments Are On Pace to Grow 6.9 Percent in 2014 [online] Available at: http://www.gartner.com/newsroom/id/2692318. [Accessed 5 May 2014].

Gavurová, B., 2011. The Balanced Scorecard System in Enterprise Management. (Systém Balanced Scorecard $\mathrm{v}$ podnikovom riadení). Ekonomický časopis, 59(2), pp.163-177.

Gavurová, B., 2012. Source Identification of Potential Malfunction of Balanced Scorecard System and Its Influence on System Function. E+M Ekonomie a management, 15(3), pp.76-90.

Gavurová, B., Šoltés, M. and Balloni, A. J., 2014. The Economic Importance of Using of ICT in the Health System (Ekonomický význam využívania informačno - komunikačných technológií v systéme zdravotníctva). Ekonomický časopis. 62(1), pp.83-104. 
Google Inc., 2014. Android market. [online] Available at: https://market.android.com/ [Accessed 5 May 2014].

Holzer, A. and Ondrus, J., 2011. Mobile application market: a developer's perspective. Telematics Informatics, 28(1), pp.22-31.

Kenney, M. and Pon, B., 2011. Structuring the Smartphone Industry: Is the Mobile Internet OS Platform the Key? Journal of Industry, Competition and Trade, 11(3), pp.239-261.

Kim, CS., Oh, EH., Yang, KH. and Kim, JK., 2010. The appealing characteristics of download type mobile games. Service Business, 4(3/4), pp.253-269.

Kim, J., Lee, S., Geum, Y. and Park, Y., 2012. Patterns of innovation in digital content services: the case of app store applications. Innovation: Management, Policy \& Practice, 14(4), pp.540-556.

Kim, J., Park, Y., Kim, Ch. and Lee, H., 2014. Mobile application service networks: Apple's App Store. Service Business, 8(1), pp.1-27.

Kimbler, K., 2010. App store strategies for service providers. In: Proceedings of the 14th international conference on intelligence in next generation networks (ICIN), 11-14 October 2010, Berlin, Germany, pp.1-4.

Laudon, K., Traver, C. 2010. E-commerce: business, technology, society. 6th edn. New York: Prentice-Hill.

Müller, R. M., Kijl, B. and Martens, J. K. J., 2011. A comparison of interorganizational business models of mobile App Stores: there is more than open vs. closed. Journal of Theoretical and Applied Electronic Commerce Research, 6(2), pp.63-76.

Murray, K. B., Liang, J. and Haubl, G., 2010. ACT 2.0: the next generation of assistive consumer technology research. Internet Research, 20(3), pp.232-254.

Suh, Y., Lee, H. and Park, Y., 2012. Analysis and visualization of structure of smartphone application services using text mining and the set-covering algorithm: a case of App Store. International Journal of Mobile Communications (IJMC), 10(1), pp.1-20.

Szabo, Z. K., Šoltés, M. and Herman, E., 2013. Innovative Capacity and Performance of Transition Economies: Comparative Study at the Level of Enterprises. E+M Ekonomie a Management, 16(1), pp.52-68.

Šoltés, V. and Gavurová, B., 2013. Application of the cross impact matrix method in problematic phases of the Balanced Scorecard system in private and public sector. Journal of Applied Economic Sciences, 8(1), pp.99-119.

Užík, M. and Šoltés, V., 2009. The Effect of Rating Changes on the Value of a Company Listed in the Capital Market. E $+M$. Ekonomie a management, 12(1), pp.49-55.

Verkasalo, H., 2011. An international study of smartphone usage. International Journal of Electronic Business, 9(1/2), pp.158-181. 
Wang, Y. S., Lin, H. H. and Luarn, P., 2006. Predicting consumer intention to use mobile service. Information Systems Journal, 16(2), pp.157-179.

White, M., 2010. Information anywhere, any when: the role of the smartphone. Business Information Review, 27(4), pp.242-247.

Wooldridge, D. and Schneider, M., 2011. Exploring the Freemium Model with In-App Purchase. In Wooldridge, D. and Schneider, The Business of iPhone and iPad App Development. Apress, pp.207-251.

\section{ABOUT THE AUTHORS}

Dejan Erić, Professor, PhD.

Institute of Economic Sciences,

Zmaj Jovina 12, 11000 Belgrade, Serbia

e-mail: dejan.eric@ien.bg.ac.rs

Radovan Bačík, PhDr., PhD. MBA

Faculty of management, Department of Marketing and International Trade,

University of Prešov in Prešov

Konštantínova 16, 08001 Prešov, Slovakia

e-mail: radovanbacik@gmail.com

Igor Fedorko, Mgr.

Faculty of management, Department of Marketing and International Trade, University of Prešov in Prešov

Konštantínova 16, 08001 Prešov, Slovakia

e-mail: igor.fedorko@smail.unipo.sk 